\section{DIGITAL COMMONS \\ @ UNIVERSITY OF SOUTH FLORIDA}

\section{Revista Surco Sur}

Article 13

$12-20-2011$

\title{
Lezama en Lunes, Lunes en Lezama
}

Elizabeth Mirabal

Carlos Velazco

Follow this and additional works at: https://digitalcommons.usf.edu/surcosur

Part of the Bilingual, Multilingual, and Multicultural Education Commons, Creative Writing Commons, Critical and Cultural Studies Commons, and the Latin American Languages and Societies Commons

\section{Recommended Citation}

Mirabal, Elizabeth and Carlos Velazco. 2011. Lezama en Lunes, Lunes en Lezama. Revista Surco Sur, Vol. 2: Iss. 4, 36-44.

DOI: http://dx.doi.org/10.5038/2157-5231.2.4.13

Available at: https://digitalcommons.usf.edu/surcosur/vol2/iss4/13

This CRITERIO ATENTO is brought to you for free and open access by the Open Access Journals at Digital Commons @ University of South Florida. It has been accepted for inclusion in Revista Surco Sur by an authorized editor of Digital Commons @ University of South Florida. For more information, please contact digitalcommons@usf.edu. 


\section{Elizabeth Mirabal y Carlos Velazco}
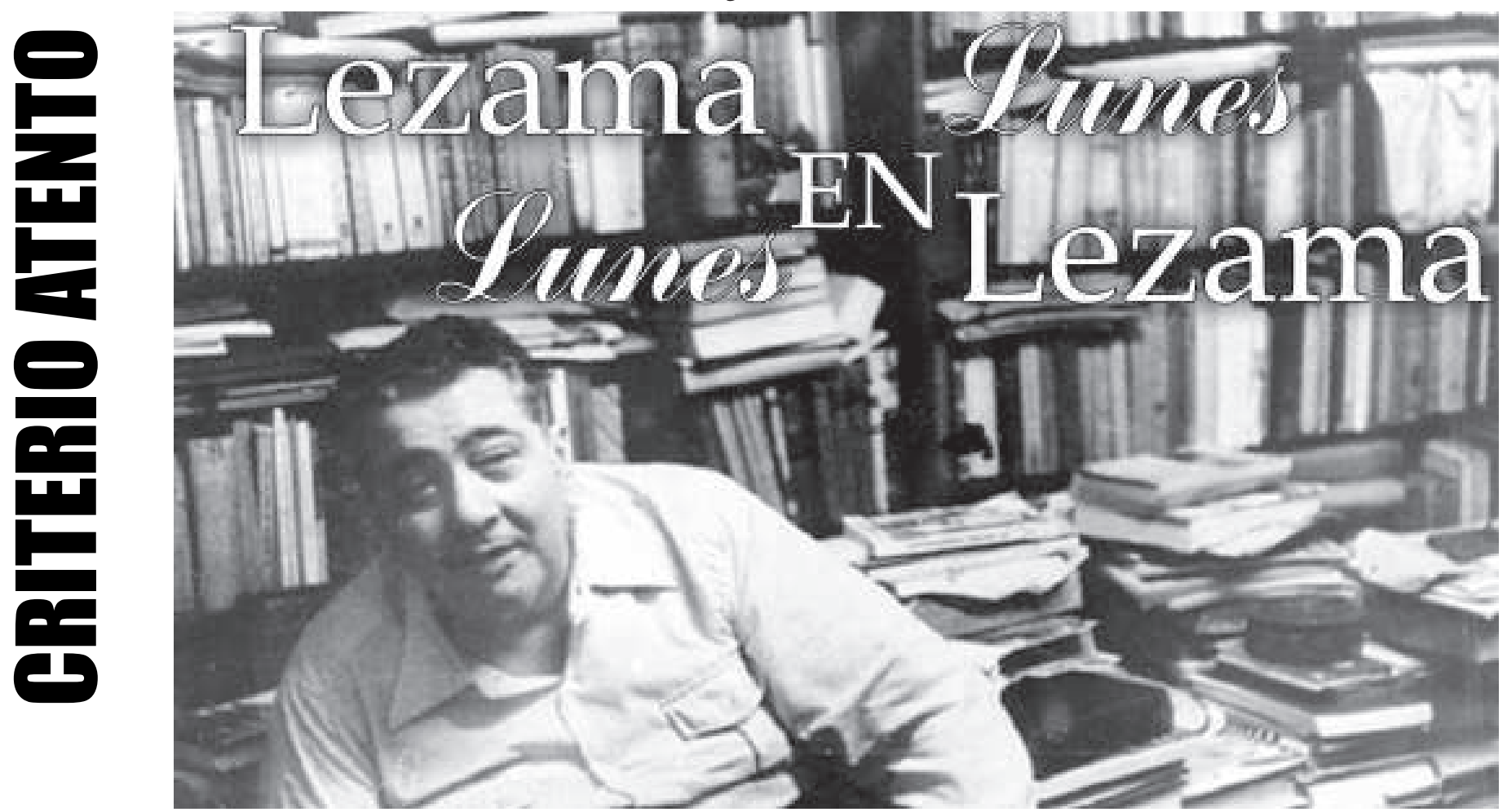

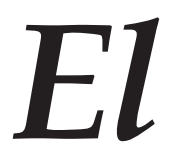

23 de marzo de 1959, el magazine Lunes de Revolución dejaba clara una postura: "Nosotros [...] pensamos que es hora de que nuestra generación [...] tenga un medio donde expresarse, sin comprometerse con figuras pasadas, posiciones y figuras que creemos en trance de pasar a la historia... si realmente lo merecen". ${ }^{1}$ Esta declaración era apenas el preámbulo de una etapa que pretendía comenzar sin antecedentes (téngase en cuenta que se había valorado llamar al suplemento Punto de partida) y que ese deseo implicaba una negación beligerante, porque no resultaba para nada casual que el primer nombre pensado para Lunes fuese Punto de mira.

La idea sartreana del compromiso intelectual adquiría una coherencia innegable con las urgentes necesidades de una revolución triunfante en el plano de la cultura. Se había derrocado a una dictadura y tal parecía que el arribo de los jóvenes rebeldes a cada una de las ciudades y caseríos del país había marcado el año cero en la historia nacional. En el campo literario estaba en juego el poder cultural y existían distintas tendencias con intereses específicos en torno a ese capital simbólico. La situación de las fuerzas en pugna era desigual. Sin embargo, no hay duda de que los intelectuales nucleados en torno a Lunes, ostentaban en ese primer momento una condición privilegiada. Carlos Franqui había luchado en la Sierra Maestra y una vez terminada la guerra fue nombrado director del periódico Revolución, órgano del Movimiento 26 de Julio. Como elementos activos y actuantes, los jóvenes escritores se sentían capaces de modificar el campo cultural y armar una visión propia de la sociedad y su posición en ella.

Es en esos primeros meses de 1959, cuando Mariano Rodríguez recordaba una reunión en la Sociedad Cultural Nuestro Tiempo, a la que llegó junto a Virgilio Piñera: “Estaban Cabrera Infante, Heberto Padilla, Carlos Franqui y César Leante. Justo en el momento en que Leante alzaba el poemario Dador de Lezama, entramos nosotros. Oí que decía que aquel libro estaba manchado con la sangre y el sudor del pueblo". ${ }^{2}$ La anécdota revela que entre algunos de los que se convertirían en los colaboradores de Lunes, ya se gestaban criterios contra la figura cimera de Orígenes, emitidos desde posiciones extremistas y de exagerada efervescencia revolucionaria.

El 14 de marzo, nueve días antes del primer número de Lunes, José Álvarez Baragaño publicó "Orígenes: una impostura". Desde el primer párrafo de su artículo y empleando un lenguaje de campaña, hizo centro en "esa vacilación sensitiva, hablamos del grupo de la revista "Orígenes", bajo el imperio de José 
Lezama Lima". Se valía en todo momento de la primera persona del plural, que de ninguna manera debemos entender de cortesía, y a pesar de aclarar que no anularía el valor de la obra de Orígenes ("esos señores"), terminaba haciéndolo: "Así es, Lezama, poéticamente, representa la impotencia, porque la oscuridad sólo sirve para transmitir ideas oscuras; Lezama no transmite nada, su escritura es un esfuerzo que termina en fatiga inútil para el escritor y el lector. Lezama es un impotente verbal que no ha comprendido nunca la esencia del lenguaje". ${ }^{3}$ Baragaño, que había sido un surrealista furibundo, como recién llegado al campo cultural trataba de cuestionar a uno de los intelectuales más reconocidos y afianzados de la época. Sus estrategias de subversión solo podían calificarse de heréticas. Pero muy pronto, emergió otro medidor: "Los"originales" atacan en público y en privado al pueblo cubano diciendo que está corrompido; daban la espalda al pueblo, y ellos, los purísimos, se dedican a la abominación de la indiferencia ante el drama de sus compatriotas." La llamada exclusión simbólica, pasaba en este caso no solo por la anulación de una categoría literaria, sino también por un cuestionamiento político.

Para ese entonces José Rodríguez Feo se encontraba distanciado de Lezama Lima, pero dejó a un lado sus diferencias y contestó a Baragaño, motivado por las opiniones emitidas sobre la revista de la que fuera co-director y por un sentido ético olvidado cuando en el último número de Ciclón, esa misma semana, ponía en entredicho "la neutralidad" de varios escritores durante la dictadura de Batista, entre los que se hallaba nombrado el propio fundador de Orígenes: "Creo que todo escritor serio debe enfocar los problemas de la cultura de su país con cierto grado de mesura y veracidad. Falsear los hechos, atacar personalmente al escritor no contribuye a esclarecer el fenómeno literario o a situar en su momento histórico la obra del artista. El intelectual que quiera contribuir a crear un estado de conciencia nueva para su país no puede partir de una actitud inconsciente y mezquina". ${ }^{4}$

Rodríguez Feo reconocía la intención de tachar a Orígenes de reaccionario al situar en 1936 (de espaldas a la Guerra Civil Española) el surgimiento de una revista aparecida en 1944, notaba un proceder demagógico y advertía los peligros que implicaba pretender deslegitimar el valor de un grupo, cuya obra era relevante más allá del panorama literario cubano: "Querer negar toda una generación, con cuyo credo estético podemos estar reñidos, no es hacer obra revolucionaria. Querer abolir una tradición literaria, que de por sí es pura tontería, es ser reaccionario". ${ }^{5} \mathrm{Sin}$ embargo, esta certeza sobre la existencia de un precedente a considerar en las letras nacionales, sin duda justa, resultaba incoherente con un trabajo de Piñera (publicado bajo la anuencia de Rodríguez Feo en el primer número de Ciclón) en el que se decía que la literatura cubana solo existía en los manuales. De esta visión iconoclasta -a la que Baragaño apeló en algún momento de su contrarréplica-, renegaría Virgilio tiempo después. En sentido general, no deja de llamar la atención el considerable giro de criterio que se produce en Rodríguez Feo con tan poco tiempo de diferencia. Este cambio repentino quizá se explique si se tiene en cuenta que Baragaño en sus ataques no solo se concentraba en Lezama, sino que los hacía extensivos al Orígenes con el que Rodríguez Feo había estado raigalmente vinculado.

En una polémica con un punto de debate que a veces se desdibujaba, Baragaño desdeñaba la validez de la poesía cubana sin nexo con el compromiso, para después lanzar un dardo político, directo y agresivo: “En la 
cultura como en la guerra, neutralidad significa inteligencia con el enemigo o posibilidad de inteligencia. Por otra parte, Orígenes, cuando rompió por un momento su neutralidad se declaró contra la comedia política, es decir, contra el drama del pueblo cubano" ${ }^{\prime}{ }^{6}$

En medio de este proceso de depuración que tenía lugar desde disímiles publicaciones culturales, apareció en la sección "Libros" de Lunes de Revolución la crítica de Enrique Berros "Un cubano en la poesía", la primera envestida real del suplemento contra el grupo Orígenes, y en particular, contra la figura de Lezama Lima. A juicio de Berros, Cintio Vitier representaba la actitud de todo un grupo "que se empeñan en vivir en una mítica torre de marfil que, aunque habitación idónea para el monje medieval, es escasamente adecuada para el intelectual que tiene que vivir y trabajar en una época en la cual la violencia se ha convertido en ciencia y los aspectos económicos sociales de la realidad se han convertido en la realidad misma". ${ }^{7}$ Berros acudía a una estrategia de ruptura, para desligarse de las dos tendencias en que, según su criterio, Lezama Lima había dividido la actitud de los intelectuales: iconoclasia e iconodulia (es decir, servidumbre ante una imagen).

Haciendo un recuento de lo que denomina la "reacción antiorigenista" del magazine, Idalia Morejón Arnáiz comenta la siguiente nota de presentación en Lunes de Revolución a dos poemas de Ángel Augier, Tiempo muerto (Cañaveral) y Tierra recobrada: "Ángel Augier es uno de los poetas de la generación de los poetas de Orígenes que nunca compartió la posición estética de Lezama Lima. Uno de los poemas que publicamos está escrito por la época en que Lezama comenzaba a formar definitivamente su mundo poético y sin embargo el poema de Augier está bien lejos de Juan Ramón Jiménez -y se menciona porque fue Jiménez quien escogió este poema para su antología cubana- y la poesía pura. La prueba es que todavía es un poema actual". ${ }^{8}$

Dice Morejón que esta "oposición forzada y artificial" entre Ângel Augier y Lezama Lima es otra manera de manifestar la reacción antiorigenista". ${ }^{9}$ Si es evidente el marcado interés del redactor en destacar otras alternativas literarias a Lezama Lima, la verdadera oposición de Augier con Lezama la encontramos -y no forzada ni artificial- en una carta del propio Augier a José Antonio Portuondo: "La gente de Espuela sigue sacando Orígenes, que a veces dan ganas de llamarla separando o suprimiendo la tercera sílaba...". ${ }^{10}$ Es decir, Orines. No se trata en este caso de un material para publicar, pero permite ilustrar que no es una oposición impuesta, y más que eso, que la negación literaria de Lezama Lima no es una singularidad de los herederos de Ciclón.

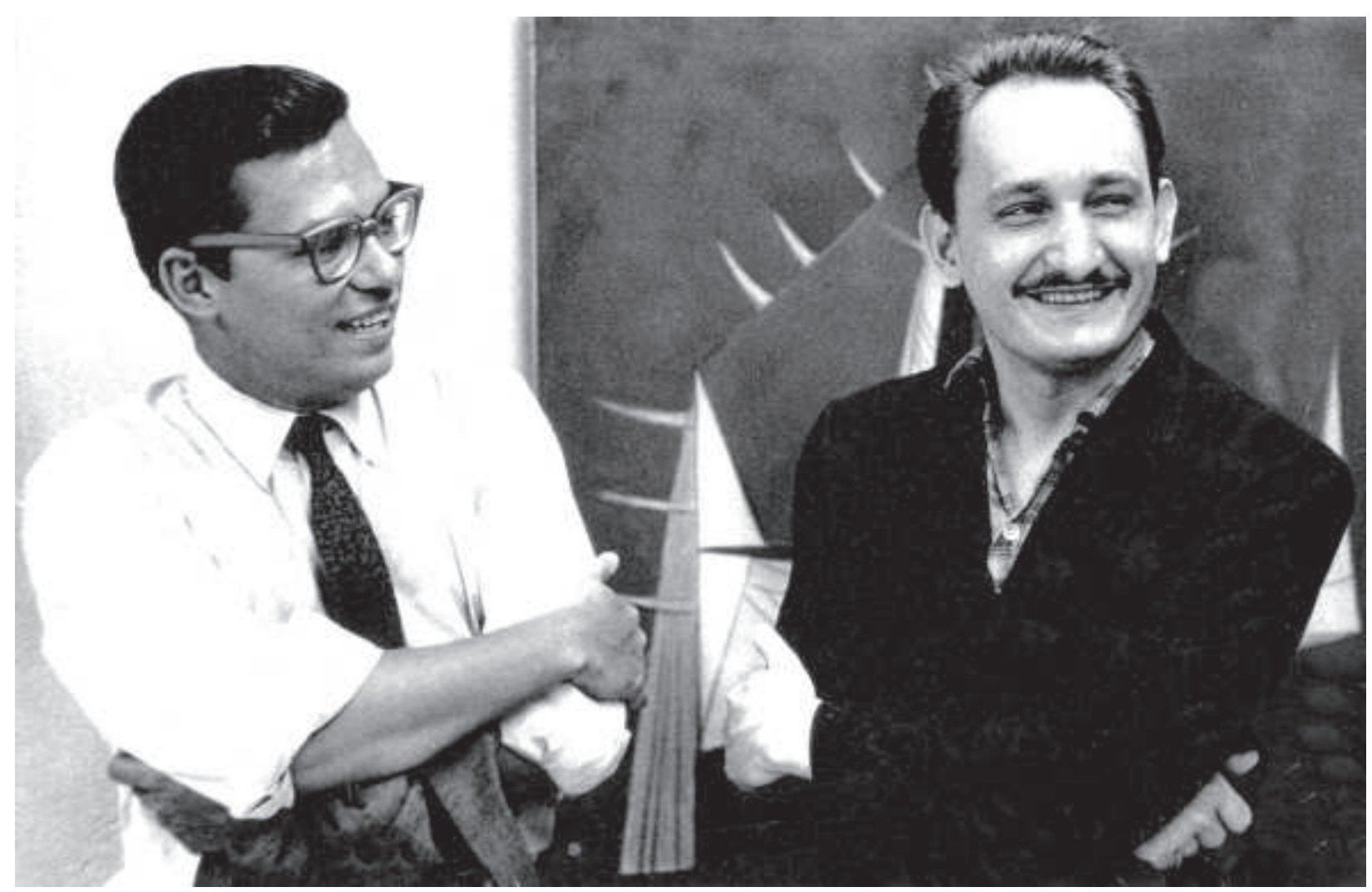

Guillermo Cabrera Infante y José Álvarez Baragaño 
Quizás sea Idea de la Revolución de Antón Arrufat, el texto que mejor ilustre el significado y la recepción del hecho revolucionario por parte del grupo de los jóvenes intelectuales nucleados en torno a Lunes, que habían despertado de una realidad caótica, ajena, hostil y que regresaban del exilio político o económico. Las esperanzas postergadas coincidían con las de la nueva sociedad que se quería construir. Por tanto, esos escritores que apostaban por la comunicación con el lector, tenían la posibilidad multiplicada por quinientos mil ejemplares de llegar masivamente a las puertas de las casas y ser discutidos en las calles.

Para quienes criticaban la actitud hermética y trascendentalista de Orígenes como manifestación generacional de identidad, la negación de los escritores anteriores coincide con la negación del pasado, ahora desde los valores estéticos del nuevo momento político: "Ya no es posible, literariamente posible, una concepción de la poesía, por ejemplo, como una iluminación del ser mediante el éxtasis del Elegido. La suntuosa imagen de Lezama, su "elegancia" verbal, su noción de las esencias inmutables, su sentido a-histórico, la explotación de temas que no comprometen ningún valor, se corresponden con los grandes latifundios, las bellas fincas y los poderosos señores. Su obra, como la clase social que refleja, está liquidada. La resonancia de su genio poético se redujo al mínimo". ${ }^{11}$ Arrufat como vanguardia reciente cuestiona a la consagrada, recurre a estrategias de diferenciación y ruptura, para afirmarse como generación. Difiere para existir. A finales de 1959, en su comentario sobre la antología de Roberto Fernández Retamar y Fayad Jamís publicado en el número 39 del magazine, confesaba que para los poetas cubanos era un verdadero problema, una preocupación angustiosa, escribir una poesía sin el influjo de Lezama, durante mucho tiempo el maestro del patio. Esta alusión, revela una lucha generacional disfrazada con ataques políticos. Los más jóvenes buscaban rabiosamente devorar a sus predecesores y perpetuar el espíritu anti-origenista de Ciclón en Lunes. En su afán por ser otros, censuraban sus obras, tachando el más mínimo vestigio lezamiano. Como nos ha contado el propio Arrufat, la confluencia de los más lozanos escritores era muy singular: "Aquel tipo de relación, el interés común por la pintura, el teatro, el cine, la literatura norteamericana e inglesa, aparte de trabajar todos en Lunes, contribuyeron a nuestra unidad generacional, que no era exactamente una unidad como la definida por Ortega y Gasset, no estábamos separados quince años de la generación anterior ni teníamos nacimientos cercanos. [...] sin embargo, prevalecían unidades espirituales, mentales, que nos hacían tener una especie de cohesión, una cohesión un poco disparatada, de discutir uno con el otro". ${ }^{12}$

La respuesta de César Leante a Mario Parajón, Jorge Mañach, Anita Arroyo y a aquellos que convocaban a un estilo menos agresivo por parte del magazine, dilataba el rechazo a la fuerte impronta de Orígenes desde un prisma también generacional. Reconocía que no tenían obra, pero que aun así, no asumirían un modelo, a lo sumo, con la virtud de ser negativo: "Se quería que no se juzgase la posición estética de la generación que nos precedió, [...] que continuásemos aceptándolos como "maestros" cuando ya la Revolución había hecho evidente que era la generación más incapaz que había conocido nuestra República". ${ }^{13}$

Heberto Padilla escribiría en diciembre de 1970 que alrededor de los años cincuenta había llegado a la conclusión de que en la calle Trocadero había una casa que dinamitar, un arsenal donde surgían una poética desbordante y críptica a sus ojos, estímulos y diálogos que se iban convirtiendo en doctrinales. ${ }^{14}$ Para dar cumplimiento a esa idea, publicó el 7 de diciembre de 1959 en Lunes de Revolución "La poesía en su lugar".

Esta es, entre las críticas a Lezama y a Orígenes, la que lleva esa actitud de negación a tocar la puerta de la propia redacción de Lunes. Constituye el único trabajo de este tipo que desembocará en una polémica entre dos miembros del magazine. Padilla la inicia con el reproche a Virgilio Piñera y su poesía de sumisión a Lezama Lima, tesis que le sirve para enterrar literariamente a Piñera. Al evocar el momento de aparición de Enemigo rumor de Lezama, hace su valoración de autor y poemario: "No lo culpo de la desgracia de aquellos poemas desmañados, recargados, hechos de viejos cantos ultraístas, valerianos y gongorinos. Cada uno tiene sus limitaciones. Lo imperdonable es que un grupo de gentes aparentemente dotadas para la comprensión 
de lo poético, confundieran a tal punto la verdad de la poesía. En el año 44, donde tan claro estaba el panorama universal de la poesía, "Enemigo rumor" es el salto cien años atrás..."15 Pero sin dudas, el ataque político a la obra y la persona de Lezama podía leerse casi como una condena oficial: "Lezama -tal vez justificando su escape para no enjuiciar el drama cubano-, nos había afirmado tercamente que "un país frustrado en lo esencial político puede hallar virtudes y expresiones por otros cotos de mayor realeza"; pero, he aquí como todos hemos constatado que no puede haber cotos de ninguna realeza en un país aparentemente frustrado políticamente y que la única función posible del escritor es participar del drama de su país y de su tiempo" ${ }^{16}$ Cabrera Infante diría sobre este texto que cuando lo vio publicado tuvo la impresión de que había soltado una jauría contra un hombre atado. ${ }^{17}$

En medio de la descrita manifestación antiorigenista de muchos jóvenes, Padilla marca distancia entre él y "los que han puesto en el ataque a Lezama todo el resentimiento de su insuficiencia creadora", sin duda en franca alusión a Baragaño y Leante. La suya es una "discrepancia fundamental" que lo lleva a enterrar a sus mayores y resistirse a la cominería intelectual de los poetas jóvenes que siguen repitiendo el ceremonial de Trocadero: "José Lezama Lima terminó ya. Como Agustín Acosta, como Pichardo Moya, como todos esos poetas mediocres que ha desenterrado la avidez de antólogo de Cintio Vitier, su nombre quedará en nuestras antologías ilustrando las torpezas de una etapa de transición que acabamos de cancelar en $1959^{\prime \prime} .{ }^{18}$

Según el testimonio del propio Padilla, todos los cambios de tipografía que ostenta La poesía en su lugar, respondieron a los cortes de Pablo Armando Fernández en un esfuerzo por quitar resentimiento a su enfoque. Fue Pablo Armando, el experto diplomático, quien visitó a Lezama luego de la aparición de este artículo. Según nos contó, le dijo: "Ya usted tiene experiencia. Por aquel artículo de Juan Ramón Jiménez contra Vicente Aleixandre, Rodríguez Feo rompió relaciones con usted y Orígenes desapareció. Cuando él le reclamó, le respondió que no podía censurar a Juan Ramón. Y esa lección suya, la aprendí. En este caso, tampoco yo podía censurar a Padilla". ${ }^{19}$

Surgiría entonces lo que era de prever, la respuesta de Virgilio Piñera colocando Cada cosa en su lugar. Demostraba que era el menos lezamiano de los poetas de su generación, no sin antes coincidir en algunos aspectos con Padilla, a quien reconocía en "sus primeras actuaciones de lobo feroz." Se trata de un recorrido exhaustivo del autor por sus años en el grupo de Espuela de Plata y algún que otro poema de juventud en la tesitura de Lezama ("iqué diablos, alguna vez se ha sido joven!") hasta detenerse en su resistencia a la influencia del poeta: "Por eso, cuando Padilla tratando de poner a la poesía en su lugar y a mí de paso, habla de mi sumisión a Lezama incurre en un error de bulto. Tanto no me sometí, que además de ser expulsado de Espuela de Plata, de no habérseme permitido publicar en Nadie Parecía, hasta llegué a un gracioso cambio de arañazos y mordiscos con Lezama en los salones de la benemérita sociedad Lyceum". ${ }^{20}$

A la pregunta de si era cierto que Lunes de Revolución aplastaba a todo aquel que estuviera en desacuerdo con sus posiciones estéticas, Ambrosio Fornet responde que aplastar es un verbo muy fuerte, que se asocia con el ogro de Pulgarcito o con las cucarachas y que en cuanto a Lunes, nunca antes había oído hablar de eso. A menos que se estuviese aludiendo a la arremetida contra Lezama, pero que en ese caso, a Lezama, por sus dimensiones (tanto literarias como físicas) era imposible aplastarlo. ${ }^{21}$

Así debía entenderlo Virgilio Piñera cuando en su crítica a Padilla plantea la paradoja de un Lezama "liquidado" todavía influyente, consideración que podía leerse como un elogio al poeta: "Diga Padilla lo que diga, Lezama estuvo vivo allá por el 41. La prueba de ello es que la generación actual no ve las santas horas de quitárselo de encima. Todas las polémicas, todas las conversaciones de café y redacción de periódicos giran alrededor de Lezama. Si se da por sentado que la poesía de Lezama es una experiencia fallida en el campo de la poesía cubana, yo pregunto: ¿Qué poeta se ha visto librado, en todo o en parte de su influjo? Y es por eso precisamente por lo que hay la urgencia de liquidarlo cuanto antes, es decir, él está liquidado, pero eso no basta, pues mientras exista una sospecha de lezamismo en dichos poetas ni respirarán tranquilos ni tampoco su poesía será absolutamente personal". ${ }^{22}$

Arrufat volvería a la carga contra Lezama durante 1960 en tres ocasiones más. En Una antología lamentable, el comentario a la selección de capítulos de novelas cubanas que había hecho Lorenzo García Vega, exponía que si se tenía la curiosidad de contar las páginas 

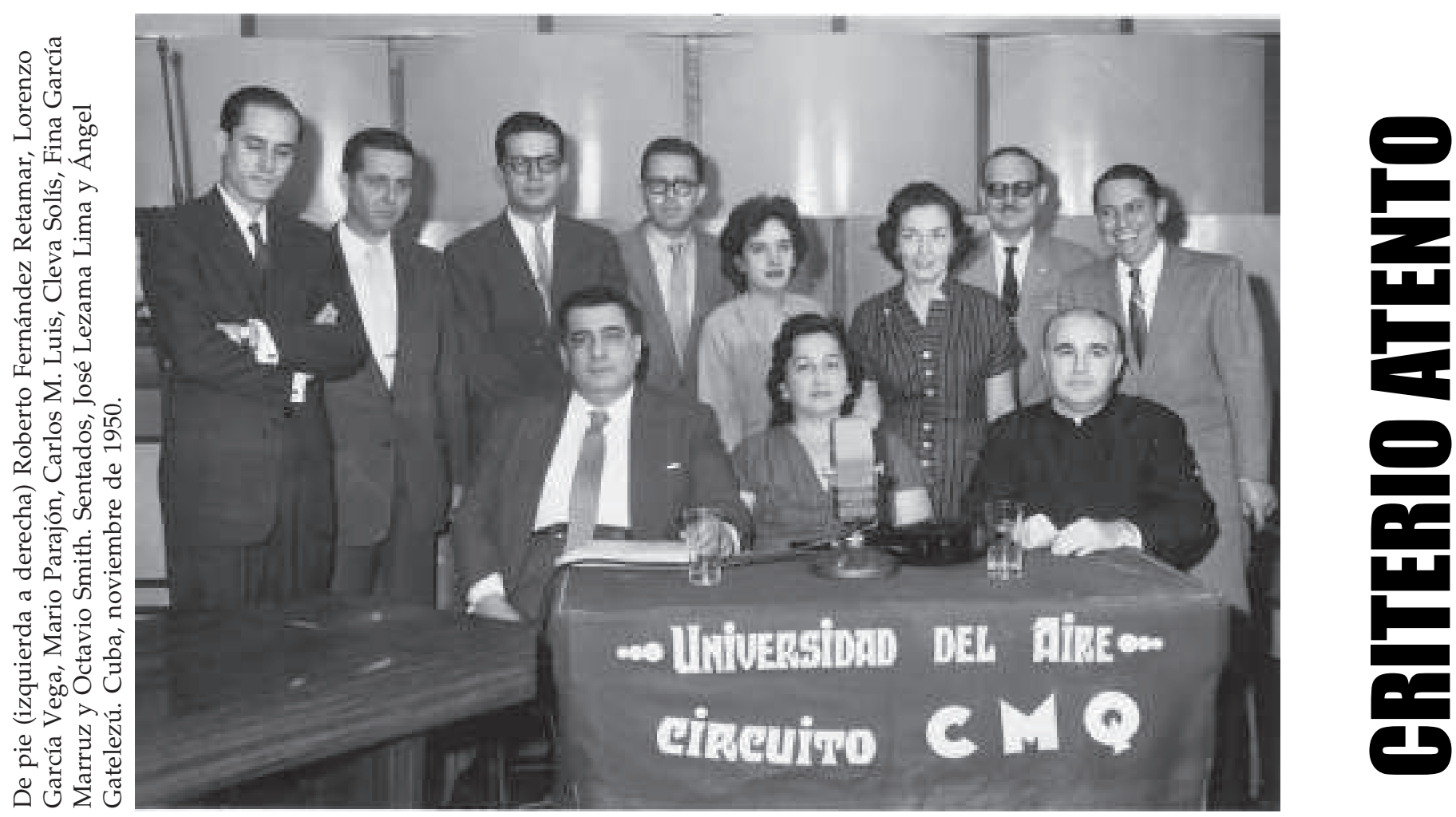

dedicadas a Lezama se comprobaría que era el novelista que acumulaba un mayor número, en contraste con Alejo Carpentier, que tenía menos, a pesar de que este último ya contaba con cuatro novelas publicadas y Lezama, solo con cuatro capítulos de una obra sin terminar. ${ }^{23}$ Continuaba asaetándolo en Saldo de una editorial: "Entre nosotros, Lezama ha dado muestras de ser el escritor más empecinado en sus defectos, con una obcecación que nada rectifica". ${ }^{24}$ Sin embargo, en este mismo trabajo ya era posible dilucidar una alabanza (adjetivos como brillante y deslumbrante así lo revelan) y el reconocimiento del temor que animaban las belicosas páginas del joven escritor: "Lezama es un maestro que devora a sus discípulos. Lo que en su prosa es hipérbole, minucioso mal gusto, frondosidad e incoherencia, retorcimiento, pero que de vez en cuando nos sorprende con una brillante asociación, una sentencia, una imagen deslumbrante, en sus seguidores es grosería y chabacanería implacable".$^{25}$ La última de las críticas la dio a conocer Arrufat en el número de Lunes donde Lezama publicaba Orfismo de Escardó. En su homenaje al poeta, Arrufat decía que Escardó era un tránsfuga, un caso aislado y original, no contaminado con el modo de escribir poesía adoptado por "la generación de Orígenes". ${ }^{26}$

Aquella común actitud hacia exponentes literarios precedentes parece descabellada hoy, por la importancia en la cultura nacional de muchos de los nombres que entonces se desacralizaban, pero es inherente al juicio literario: cuestionar en vez de aceptar de forma acrítica. Como caracterizaba Piñera a principios de 1960, con el triunfo de la Revolución, lo cultural estaba íntimamente relacionado con lo político, la joven generación rechazaba todo paliativo y la lucha por el poder cultural era entre la vieja y la nueva guardia. Los primeros se defendían, y los segundos, a tono con el nuevo proceso, atacaban. ${ }^{27}$ Se oponían de este modo a un catolicismo que no profesaban y una literatura que les parecía hermética y críptica. Apostaban por la comunicación directa con el otro y para lograrlo recurrían al teatro con insistencia, preferían la poesía inglesa por encima de las influencias de Juan Ramón Jiménez y la Generación del 27. Encontraban en Pablo Neruda y T.S. Eliot una impronta contemporánea que les costaba distinguir con la misma intensidad en Rilke, Valery o Claudel y al no estar consolidados como personalidades literarias dentro del devenir de la ciudad letrada, supeditaban el reconocimiento de los valores de un grupo anterior, a su imperiosa necesidad por autodescubrirse.

No obstante, lo que algunos han calificado como "campaña de «terrorismo cultural»" tuvo significativas atenuantes. De lo contrario, ¿cómo se le llamaría a las más de diez veces que Lezama Lima publicó en Lunes, superando el número de colaboraciones de otros intelectuales 
Mariano Rodríguez, José Rodríguez Feo y Lezama

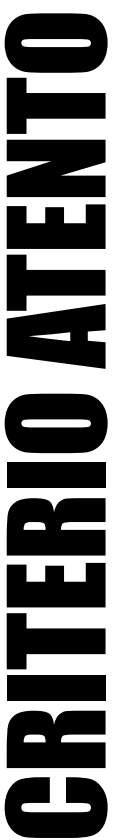

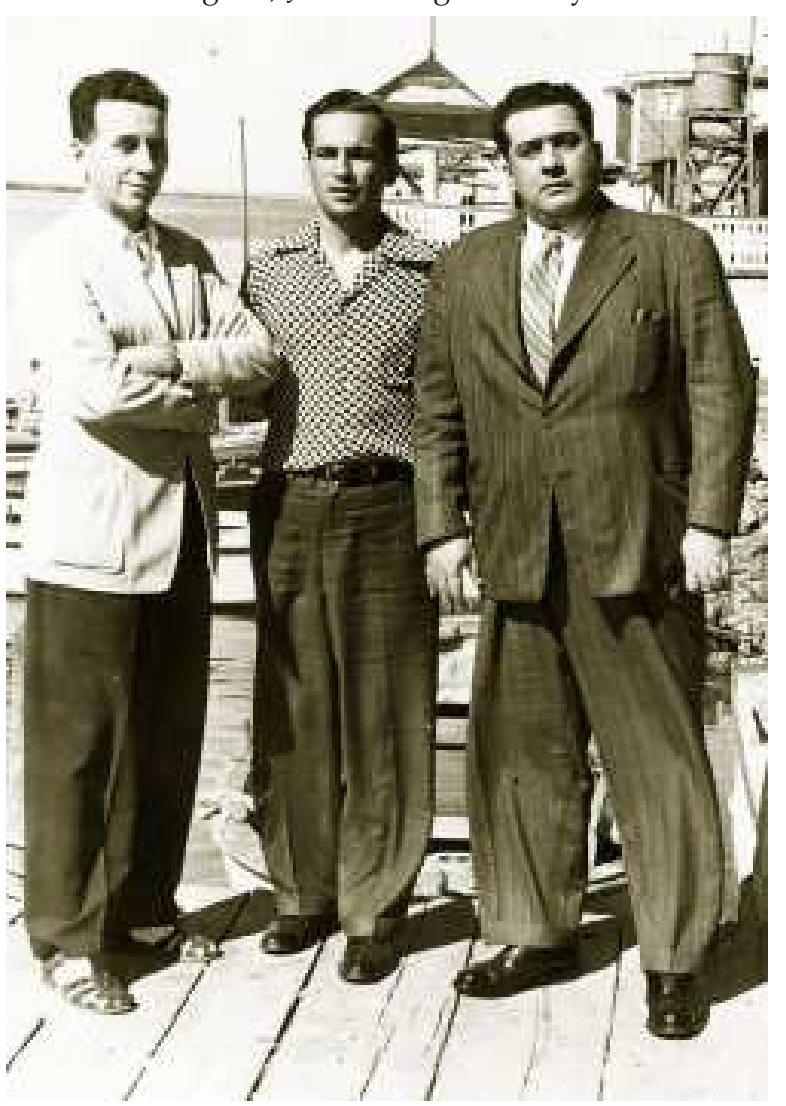

más cercanos al magazine como Fausto Canel y Jaime Sarusky? Ese mismo año 1959 aparece Lezama entre los retratados por Jesse Fernández, junto a Buñuel, Siqueiros y Lam [21, agosto 19]; un artículo suyo se incluye en el homenaje a Emilio Ballagas [26, septiembre 14]; y en el recordado número final del año $A$ Cuba con amor [40, diciembre 21], el único en colores y papel cromado, leemos su trabajo Corona de frutas. En 1960, es uno de los encuestados sobre qué libros salvar. Resulta curioso que Cabrera Infante, también interrogado sobre este asunto, coincidiera con Lezama en que resultaban imprescindibles $\mathrm{La}$ Divina Comedia, el Quijote y el teatro de Shakespeare. Su próxima contribución es el texto en homenaje a Escardó, y le seguirían Alfonso X El Sabio y Capablanca [86, diciembre 12] y Dador [87, diciembre 19]. El 1961 casi podría decirse que fue un año lezamiano en Lunes. No solo publicaría varios ensayos como Influencia en busca de Martí [93, enero 30], En una exposición de Roberto Diago [97, febrero 27], García Lorca [119, agosto 21], sino que también sus criterios como jurado del Concurso Casa fueron reproducidos [98, marzo 6], al igual que sus expectativas de que se lograra una "unidad tonal" en el inminente Congreso Nacional de Escritores y Artistas [110, junio 19]. Su texto Cautelas de Picasso aparecía en el famoso número final despidiendo al magazine. ¿Por qué accedió Lezama a colaborar en la publicación que aglutinaba a muchos de sus detractores? Tal vez por las palabras de Pablo Armando en aquella visita a Trocadero, posiblemente porque entendió que los ataques procedían de los firmantes de cada artículo. No cayó en el error de interpretar la andanada como una posición unilateral.

Valdría destacar además que en medio de las condenas, se advierten absolutos actos de distinción. Piñera, desde la temprana fecha de septiembre de 1959, en Permanencia de Ballagas, incluía a Lezama Lima, junto con Vallejo, Huidobro, Octavio Paz y Guillén, entre los admirables, milagrosos pequeños grandes poetas que había producido Latinoamérica. ${ }^{28}$ ¿Acaso no puede considerarse también la extensa nota de presentación de Oscar Hurtado al poema El coche musical como la defensa a Lezama, enarbolada por un integrante de Lunes?: "Acusar a Lezama es no abrir los ojos. Jamás en nuestras letras tuvo un poeta más seguidores y discípulos sin proponérselo, ni fue tan admirado por los que le conocieron personalmente; ni jamás se discutió tanto el idioma que usaba, ya que el castellano con Lezama sufría extraños temblores y resurgimientos. (...) Muchos detractores ha tenido el poeta ebrio de belleza y cubanidad; de cubanidad, porque un hombre que ha recogido el fruto de los insultos y del frío durante años en su Isla no dice que "nacer aquí es una fiesta innombrable" si no estuviera saturado amablemente por los poros de su paisaje. Muchos detractores ha tenido Lezama; pero ninguno lo ha hecho mejor. Ni tan siquiera igual". ${ }^{29}$

El periodista Ciro Bianchi en una entrevista en Proceso, de México, dijo que "Cabrera Infante y Heberto Padilla fueron los más encarnizados fiscales de Lezama Lima". Estas palabras llevaron al otrora joven crítico de cine G. Caín, fugazmente descrito con gorrita amarilla, espejuelos calobares y sandalias de cuero en la novela De Peña pobre, de Cintio Vitier, a decidir "hacer pedazos" lo que calificaba como "Ciropedia". Exhortó al desconocido para que mostrara una sola línea, una sola palabra, en que él hubiese atacado a José Lezama Lima, como persona o como poeta, al tiempo que recordaba que nunca se mencionaba como corresponsable de lo sucedido a Pablo Armando Fernández, que fungía como subdirector del magazine. ${ }^{30}$ 
Para la ocasión, se detuvo en un recuento bibliográfico de Orígenes en Lunes de Revolución y enfatizó que en el número 126, de octubre de 1961, treinta escritores y artistas cubanos, entre ellos siete miembros del «staff» de «Lunes», habían respondido a una encuesta para escoger los diez mejores libros cubanos de todos los tiempos y que entre los diez volúmenes que obtuvieron mayor número de votos (siete en total) estaba Enemigo rumor, de José Lezama Lima. Por si fuera poco, del grupo de Lunes, cuatro escritores (Oscar Hurtado, Virgilio Piñera, Antón Arrufat y Pablo Armando Fernández) habían escogido votar por la poesía de Lezama Lima, mientras que Lezama Lima mismo aparecía entre los votantes. ${ }^{31}$

Ambrosio Fornet, que si bien no se considera parte del cogollito de Lunes, era bastante cercano, al referirse a la lucha contra Lezama y Orígenes nos aseguró que la llevaron a cabo Baragaño, Antón y Padilla (poetas todos), pero que ni Pablo Armando ni Guillermo tuvieron nada que ver con eso. ${ }^{32}$ Aunque puede pensarse en Cabrera Infante como un provocador que tomó la precaución de no enfrascarse públicamente en las arremetidas, nos inclinamos a pensar en la posibilidad de la coexistencia de distintos criterios dentro de Lunes de Revolución, porque la polémica Padilla-Piñera, reconstruida en este mismo trabajo, no es un ejemplo aislado. Otras múltiples disparidades de opinión se hallan durante la lectura de un suplemento, tan inclusivo como para invitar a colaborar a los militantes del Partido Socialista Popular en más de una oportunidad.

Aunque Cabrera Infante, tal y como enfatizaba en su réplica a Bianchi, nunca firmó un texto contra Lezama Lima (los únicos que suscribiría, y como homenaje al escritor, fueron la parodia Nuncupatoria de un cruzado en Tres tristes tigres y el ensayo Tema del héroe y la heroína en Vidas para leerlas), no dejó de admitir mucho tiempo después de los avatares Lunes-Orígenes, que su primer error como director del magazine había sido "intentar limpiar los establos del auge literario cubano, recurriendo a la escoba política para asear la casa de las letras", porque a fin de cuentas, eso se llamaba también inquisición y podía ocasionar que muchos escritores se paralizasen por el terror. Reconocía a las claras lo que ya se ha dicho: "La revista, al contar con el aplastante poder de la Revolución (y el Gobierno) detrás suyo, más el prestigio político del Movimiento 26 de Julio, fue como un huracán que literariamente arrasó con muchos escritores enraizados y los arrojó al olvido. [...] Desde esta posición de fuerza máxima nos dedicamos a la tarea de aniquilar a respetados escritores del pasado. Como Lezama Lima, tal vez porque tuvo la audacia de combinar en sus poemas las ideologías anacrónicas de Góngora y Mallarmé, articuladas en La Habana de entonces para producir violentos versos de un catolicismo magnífico y obscuro -y reaccionario. Pero lo que hicimos en realidad fue tratar de asesinar la reputación de Lezama". ${ }^{33}$

Al ser «Nuncupatoria de un cruzado»la transcripción de una de las grabaciones magnetofónicas con que Bustrófedon parodia el estilo de varios escritores cubanos, Cabrera Infante rinde un homenaje (un contra-homenaje si se quiere) a Lezama Lima en Tres tristes tigres, a pesar de asumir la burla satírica y una mirada crítica hacia la formalización literaria. Recrea su escritura con continuas metáforas de carácter hiperbólico, acude a diversos referentes culturales, a la subordinación de oraciones y el hipérbaton, para concentrar y sobredimensionar rasgos lezamianos, partiendo de varios poemas incluidos en Dador (1960). Asume ese título, para aludir a "Nuncupatoria de entrecruzados" y, sobre todo, porque deviene de utilidad inestimable para presentar el escrito como la obra dedicada al soldado Mercader que va en busca del ajusticiamiento del infiel Trotski. No resulta fortuito que Lezama Lima figure entre los siete autores de la Isla seleccionados para su parodia. Esta inclusión implica no solo que lo considera parte de un canon literario nacional, sino también un componente indisoluble de su familia literaria.

Cabrera Infante concibió una antítesis entre el estilo de Lezama Lima "barroco y oscuro" ${ }^{34}$ y el de Virgilio Piñera "simple, casi callejero". ${ }^{35}$ Este enfoque sobre la literatura del poeta de Trocadero, no entraba en contradicción con otro criterio también manifiesto: a pesar de los valores poéticos de Piñera, no hallaba en sus versos ninguno con la belleza y la perfección de Muerte de Narciso y Enemigo rumor. Su revaloración lo conduciría al punto de aseverar que Lezama había compuesto poemas que clasificaban entre los más hermosos escritos en español en el siglo XX. Como otros autores de su generación, lo que rechazaba en él era esa "creciente oscuridad", unido al deseo perenne de erigirse en maestro absoluto. En las reuniones de la Biblioteca Nacional en 1961, Lezama discursó sobre la eternidad del arte y la permanencia de la cultura, aun con razones más que justificadas 
para denostar a Lunes. Cuando se refirió al magazine, se limitó a explicar que era propio de la juventud cometer excesos. De una vez y para siempre, Cabrera Infante descubrió en esa actitud "la personificación de la generosidad, en la literatura y en la vida". ${ }^{36}$ Nunca más lo abandonaría esa visión, ni siquiera el aciago 21 de febrero de 2005 en que encontró la muerte en Londres.

\section{Citas:}

${ }^{1}$ Lunes de Revolución, La Habana, no. 1, marzo 23, 1959, p. 2.

${ }^{2}$ Roberto Pérez León: Tiempo de Ciclón, Ed. Unión, La Habana, 1995, p. 80

3 José A[lvarez]. Baragaño: "Orígenes": una impostura» en Revolución, La Habana, 14 de marzo de 1959 , p. 2.

${ }^{4}$ José Rodríguez Feo: «La verdad sobre "Orígenes"» en Revolución, La Habana, 28 de marzo de 1959, p. 2.

${ }^{5}$ Ídem.

${ }^{6}$ Ídem.

7 Enrique Berros: «Un cubano en la poesía (Comentario a un libro de Cintio Vitier)» en Lunes de Revolución, La Habana, no.1, marzo 23, 1959, p. 2.

${ }^{8}$ Lunes de Revolución, La Habana, n o. 20, agosto 3, 1959, p. 9.

${ }^{9}$ Idalia Morejón Arnáiz: «Lunes de Orígenes. Notas sobre la reacción antiorigenista en Lunes de Revolución» en El Caimán Barbudo, La Habana, año XXX, ed. 283, p. 26.

${ }^{10}$ Ángel Augier: Carta a José Antonio Portuondo, 9 de febrero de 1945, en Cuestiones privadas. Correspondencia a José Antonio Portuondo (1932-1986), Ed. Oriente, Santiago de Cuba, 2002, p. 144.

${ }^{11}$ Antón Arrufat: «Idea de la Revolución» en Lunes de Revolución, La Habana, no. 35, noviembre 16, 1959 , p. 15.

${ }^{12}$ En entrevista con los autores, 12 de diciembre de 2008.

${ }^{13}$ César Leante: «El club de los moderados» en Lunes de Revolución, La Habana, no. 37, noviembre 30, 1959, p. 14.

${ }^{14}$ Heberto Padilla: «Oír a Lezama» en La Gaceta de Cuba, La Habana, no. 88, diciembre, 1970, p. 21.

${ }^{15}$ Heberto Padilla: «La poesía en su lugar» en Lunes de Revolución, no. 38, diciembre 7, 1959, p. 5.

${ }^{16}$ Ibíd., p. 6.

${ }^{17}$ Guillermo Cabrera Infante: «Vidas para leerlas» en Vuelta, México, no. 41, abril, 1980, p. 8.

18 Ídem.

${ }^{19}$ En entrevista con los autores, 22 de abril de 2008.

${ }^{20}$ Virgilio Piñera: «Cada cosa en su lugar» en Lunes de Revolución, La Habana, no. 39, diciembre, 1959, p. 11.

${ }^{21}$ En entrevista con los autores, 8 de marzo de 2009.

${ }^{22}$ Virgilio Piñera: op. cit., p. 12.
${ }^{23}$ Antón Arrufat: «Una antología lamentable» en Lunes de Revolución, La Habana, no. 59, mayo 16, 1960, p. 10.

${ }^{24}$ Antón Arrufat: «Saldo de una editorial» en Lunes de Revolución, La Habana, no. 64, junio 20, 1960, p. 20.

${ }^{25}$ Ibíd., p. 22.

${ }^{26}$ Antón Arrufat: «Lo que será de Escardó» en Lunes de Revolución, La Habana, no. 83, octubre 31, 1960, p.13.

${ }^{27}$ Virgilio Piñera: ed. loc.

${ }^{28}$ Virgilio Piñera: «Permanencia de Ballagas» en Lunes de Revolución, La Habana, no. 26, septiembre 14, 1959, p. 5.

${ }^{29}$ Oscar Hurtado: Nota de presentación al poema «El coche musical» en Lunes de Revolución, La Habana, no. 76, septiembre 12, 1960, p. 15.

${ }^{30}$ Guillermo Cabrera Infante: «Quién es Ciro Bianchi» en ABC literario, España, noviembre 24, 1994, pp. 16-17.

${ }^{31}$ Guillermo Cabrera Infante: «Orígenes en Lunes» («Quién es Ciro Bianchi») en ABC literario, España, noviembre 24, 1994, p. 20.

32 En entrevista con los autores, 8 de marzo de 2009.

${ }^{33}$ Guillermo Cabrera Infante: «Mordidas del caimán barbudo» en Mea Cuba, Alfaguara, Colombia, 1999, pp. 93-94.

${ }^{34}$ Guillermo Cabrera Infante: «Tema del héroe y la heroína» en Vidas para leerlas, Alfaguara, Colombia, 1998, p.15.

${ }^{35}$ Ídem.

${ }^{36}$ Íbidem., p.36.

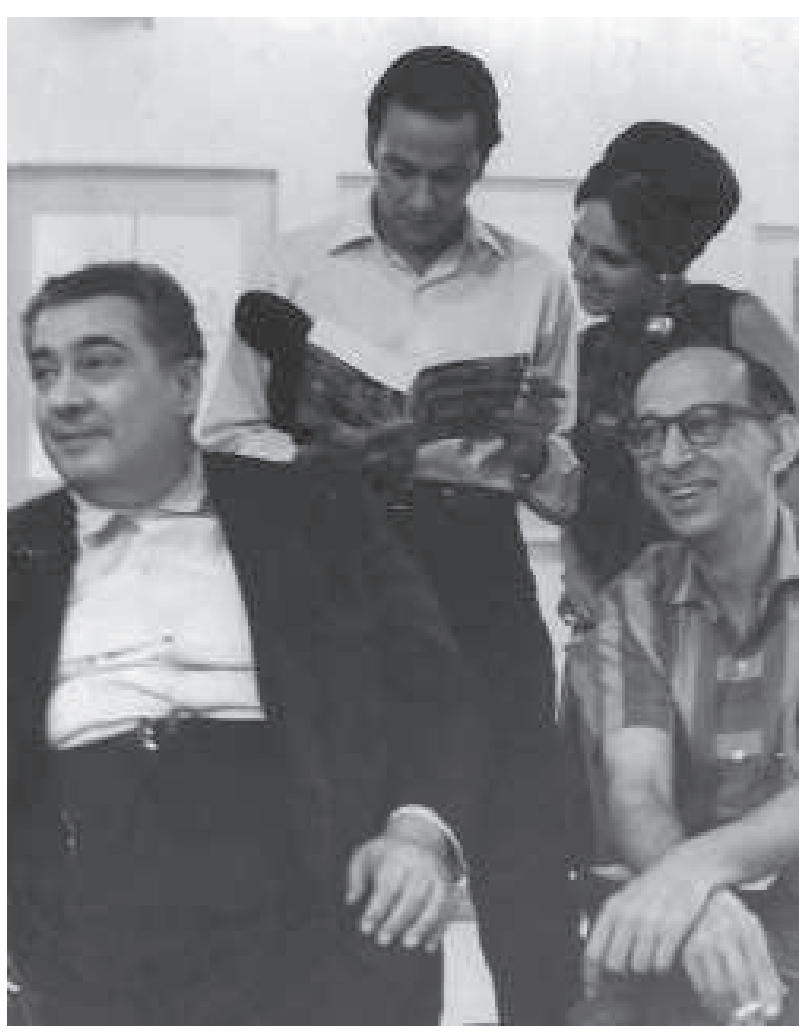

José Lezama Lima y Virgilio Piñera. Detrás, Jorge y Margarita Camacho. En Casa de las Américas, 1967. 